\title{
The perineuronal glial tissue of spinal ganglia. Quantitative changes in the rabbit from youth to extremely advanced age
}

Accepted: 11 April 2006/Published online: 23 June 2006

(C) Springer-Verlag 2006

\begin{abstract}
The volumes of the nerve cell bodies and those of the enveloping satellite cell sheaths from spinal ganglia were determined by morphometric methods applied to electron micrographs in young, adult, old and very old rabbits. The mean volume of the nerve cell bodies increased progressively with age; this is probably related to the increase with age of the body size of the rabbits studied. The mean volume of the satellite cell sheaths did not differ significantly in young, adult and old animals, but was significantly smaller in very old animals. It is extremely unlikely that this marked reduction in the volume of the satellite cell sheath is the result of a pathological process. The mean value of the volume ratio between the satellite cell sheaths and the related nerve cell bodies did not differ significantly in young and adult animals, but was significantly smaller in old and very old animals. This ratio was particularly low in very old animals. Our analysis showed that in each age group the volume of the satellite cell sheath is linearly related to the volume of the related nerve cell body. This result suggests that in rabbit spinal ganglia the quantitative relations between glial and nervous tissue are tightly controlled throughout life. It is suggested that ganglionic neurons release signals to influence and control the volume of their associated glial tissue. Since satellite cells have important support roles for the neurons they surround, it is likely that the marked reduction in the volume of perineuronal sheaths in the extremely advanced age is accompanied by a reduction of those roles, with negative consequences for neuronal activity.
\end{abstract}

C. Martinelli and P. Sartori contributed equally to this paper.

C. Martinelli · P. Sartori - S. De Palo · M. Ledda · E. Pannese Institute of Histology, Embryology and Neurocytology, University of Milan, Via Mangiagalli 14, 20133 Milan, Italy

E. Pannese ( $\square)$

Viale S. Michele del Carso 15,20144 Milan, Italy

E-mail: ennio.pannese@unimi.it

Tel.: + 39-02-50314660

Fax: $+39-02-50314670$
Keywords Dorsal root ganglia $\cdot$ Aging ·

Peripheral neuroglia $\cdot$ Neuron-glia interactions .

Perineuronal satellite cells

\section{Introduction}

After it was shown that interactions between nerve and glial cells are reciprocal, a wealth of information on the functional and metabolic interactions between glial and nervous tissue has accumulated. By contrast, quantitative histological data on the relations between these two tissues are scarse, particularly at the level of the individual neuron. There are several reasons for this lack of information. In most regions of the nervous system glial and nerve cells are intimately and complexly intermingled, so it is not possible to determine which glial cells are related to an individual neuron. Furthermore, both glial and nerve cells are often irregular in shape, so it is difficult to determine their volume with satisfactory precision. In sensory ganglia, on the other hand, each nerve cell body is usually enveloped by a discrete group of glial cells that forms the perineuronal sheath. These cells are usually called satellite cells and will be referred to as such in this paper. The perineuronal satellite cell sheath is sharply separated from the sheaths encircling the adjacent nerve cell bodies by connective tissue. Thus, in these ganglia each nerve cell body plus its satellite cell sheath constitutes a discrete unit (for more details see Pannese 1981, 1994). Furthermore, contrary to the situation in most regions of the nervous system, each glial (= satellite) cell is associated with one neuron only. This organization together with the fairly regular shape of nerve cell bodies and their satellite cell sheaths renders sensory ganglia particularly suitable for studying the quantitative relations between glial and nervous tissue at the level of the individual neuron. Light microscope studies have shown that in spinal ganglia the number of satellite cells associated with a nerve cell body increases with increasing the volume of the latter (Pannese 1960, 1964; Humbertson et al. 1969; Ledda et al. 2004). 
Electron microscope studies have shown that the volume of the satellite cell sheath increases with increasing the volume of the nerve cell body (Pannese et al. 1972, 1975).

The above studies were carried out in adult animals and little is known of the quantitative relations between glial and nervous tissue of sensory ganglia in other periods of life. As far as we are aware, only Pannese et al. (1996, 1997a) have been concerned with this topic having investigated spinal ganglia in young and old rabbits. To determine whether the quantitative relations between glial and nervous tissue in spinal ganglia remain constant throughout life we have carried out new research examining animals in four age groups ranging from young to extremely advanced age.

\section{Materials and methods}

The present study was carried out on rabbits (Oryctolagus cuniculus) of both sexes. Rabbits aged 1 year (three animals, 3.4-3.5 kg body weight), 3.6 years (three animals, $3.6-3.8 \mathrm{~kg}$ body weight), 6.7 years (three animals, $4.0-4.2 \mathrm{~kg}$ body weight) and 8.8 years (three animals, $4.2-4.5 \mathrm{~kg}$ body weight) were used. The rabbits were cared for according to the European Community Council Directive (86/609/EEC) on the use of laboratory animals. The dates of birth of all animals were documented; all had been raised by a specialist rabbit breeder with particular attention to hygiene and regular veterinary inspections and had been fed an unrestricted diet. Because the mean life span of the normal healthy Oryctolagus is approximately 5.6 years (Harkness and Wagner 1983) and the maximal life span is approximately 8 years (Weisbroth et al. 1974), the 1-year-old rabbits were young, the 3.6-year-old rabbits were adult, the 6.7-year-old rabbits were old and the 8.8-year-old animals were very old.

The animals were perfused transcardially with a solution containing $2 \%$ formaldehyde and $2 \%$ glutaraldehyde in $0.1 \mathrm{M}$ sodium cacodylate buffer $(\mathrm{pH} 7.3$ ) under deep anaesthesia with Nembutal i.p. $(80 \mathrm{mg} / \mathrm{kg})$. After fixation for about $3 \mathrm{~h}$, the thoracic spinal ganglia were removed, washed in cacodylate buffer $(0.2 \mathrm{M}, \mathrm{pH}$ 7.3) for $2 \mathrm{~h}$ and then postfixed on ice for $1.5 \mathrm{~h}$ in $2 \%$ $\mathrm{OsO}_{4}$, buffered with $0.1 \mathrm{M}$ sodium cacodylate. The specimens were washed in distilled water, stained with $2 \%$ aqueous uranyl acetate, dehydrated in alcohol and embedded in Epon-Araldite resin.

As even during optimum fixation, dehydration and embedding there is some degree of cellular swelling or shrinkage, to study the volume ratio between the satellite cell sheaths and the related nerve cell bodies a basic assumption was that any artifactual volume changes were about the same for both in all age groups. This assumption seems justified by the fact that all the ganglia used for the study satisfied the following conditions: (a) the interval between the nerve cell body and the enveloping satellite cell sheath was of uniform width; (b) the clefts between the satellite cells were of constant width; (c) neither nerve cell bodies nor perineuronal satellite cells showed signs of swelling or shrinkage; (d) neither empty areas nor clumping were observed in the connective tissue surrounding the satellite cell sheaths. Overall, 96 ganglia ( 8 for each animal) were used for this study.

The volumes of the satellite cell sheath and related nerve cell body were determined by the circle-fitting method specifically devised to estimate the sizes of these structures (see Pannese et al. 1972 for a detailed description). This method provides reliable results if the following conditions are observed: (1) the sections used pass near the centre of the nerve cell body, and (2) the nerve cell bodies are indeed approximately spherical. To verify that this was the case, we carried out a preliminary light microscope study on serial semithin sections ( $1 \mu \mathrm{m}$ thick $)$. This study revealed that there was only one nucleolus in each nerve cell body and this was centrally located in $90 \%$ of the nerve cell bodies examined; therefore the nucleolus could be used to recognize equatorial sections. Relatively few profiles of the nerve cell bodies containing the nucleolus were truly circular, most being oval. However, the profiles of the nerve cell bodies whose least diameter was $75 \%$ or more of the maximum diameter could be considered nearly circular. We found that $70 \%$ of the nerve cell body profiles were circular or approximately so. On the bases of these observations and of the theoretical analysis of Hennig (1967) we felt justified in using this method to determine the volume of the satellite cell sheaths and related nerve cell bodies in rabbit spinal ganglia. The reliability of the circle-fitting method was previously assessed by comparing the results obtained in rabbit spinal ganglia by means of this method with those obtained by one of the new generation procedures (the nucleator method, Gundersen 1988) and with those obtained by serial sectioning. The latter method is the most direct and accurate procedure presently available for estimating cell size. The comparison (Pannese et al. 1997b) showed that: (1) the results obtained by the circlefitting method are closely similar to those determined by the nucleator procedure; (2) the results obtained by the above two methods deviated by less than $2 \%$ from those obtained by serial sectioning.

For each ganglion, an isotropic uniform random (IUR) thin section was obtained following the orientator procedure (Mattfeldt et al. 1990). Thin sections parallel to the IUR section, $50 \mu \mathrm{m}$ apart, were then cut. These sections were examined under the electron microscope. All units (of whatever size) in which the nucleolus of the nerve cell body was evident, were photographed. Photographs were taken at an initial magnification of 2,500x; the negatives were enlarged $4 \times$ to give prints with a final magnification of $10,000 \times$. In total 190 units from young rabbits, 156 units from adults, 195 units from old rabbits and 155 units from very old rabbits were photographed using the same electron microscope. With the aid of a digitising tablet connected to a computer, the profile area of the nerve 
cell body and that of its associated satellite cell sheath, nuclei excluded, were evaluated in each unit. From the values obtained, the volumes of each nerve cell body and its satellite cell sheath were calculated. The satellite cell nuclei were excluded in order to avoid overestimation of the volumes of the satellite cell sheaths which presented one or more nuclei in the photographed sections. Finally, for each unit the volume ratio between the satellite cell sheath and the related nerve cell body was evaluated.

The values obtained for the three rabbits in each age group were compared by one-way ANOVA to establish whether they differed significantly. Subsequently, the values obtained for each age group were compared by one-way ANOVA. When ANOVA revealed significant differences, the post hoc Tukey test for multiple comparisons was used to identify differences between individual age groups. Values were expressed as means \pm SEM. Both for ANOVA and post hoc Tukey test, differences were considered significant for $P$ values $<0.05$. All data analyses were carried out using SPSS 11.0 software.

\section{Results}

The general organization of the spinal ganglia and in particular the morphological relations between the nerve cell bodies and satellite cell sheaths did not change with advancing age (Figs. 1, 2).

The quantitative results obtained for each animal are shown in Table 1; the mean results for each of the four age groups are shown in Table 2.

The mean volume of the nerve cell bodies increased progressively with age (Fig. 3a). This volume was $\sim 64 \%$ larger in the very old animals than in young animals.

As shown in Fig. 3b, the mean volume of the satellite cell sheaths did not differ significantly in young, adult and old animals, but was significantly smaller in very old animals. This volume was $\sim 54 \%$ lower in the very old animals than in young animals.

The mean value of the volume ratio between the satellite cell sheaths and the related nerve cell bodies
Fig. 1 Electron micrograph showing a unit consisting of a nerve cell body $\left(\mathrm{N}_{1}\right)$ and its enveloping satellite cell sheath (sc). The section passes through the nucleolus $(n u)$ of the nerve cell body. A portion of another unit $\left(\mathrm{N}_{2}\right)$ can be seen in the upper left corner of the figure. The satellite cell sheaths of these two units are completely separated by intervening connective tissue (filled triangle). $v$ Blood vessel. Spinal ganglion of a rabbit aged 1 year. Scale bar $5 \mu \mathrm{m}$

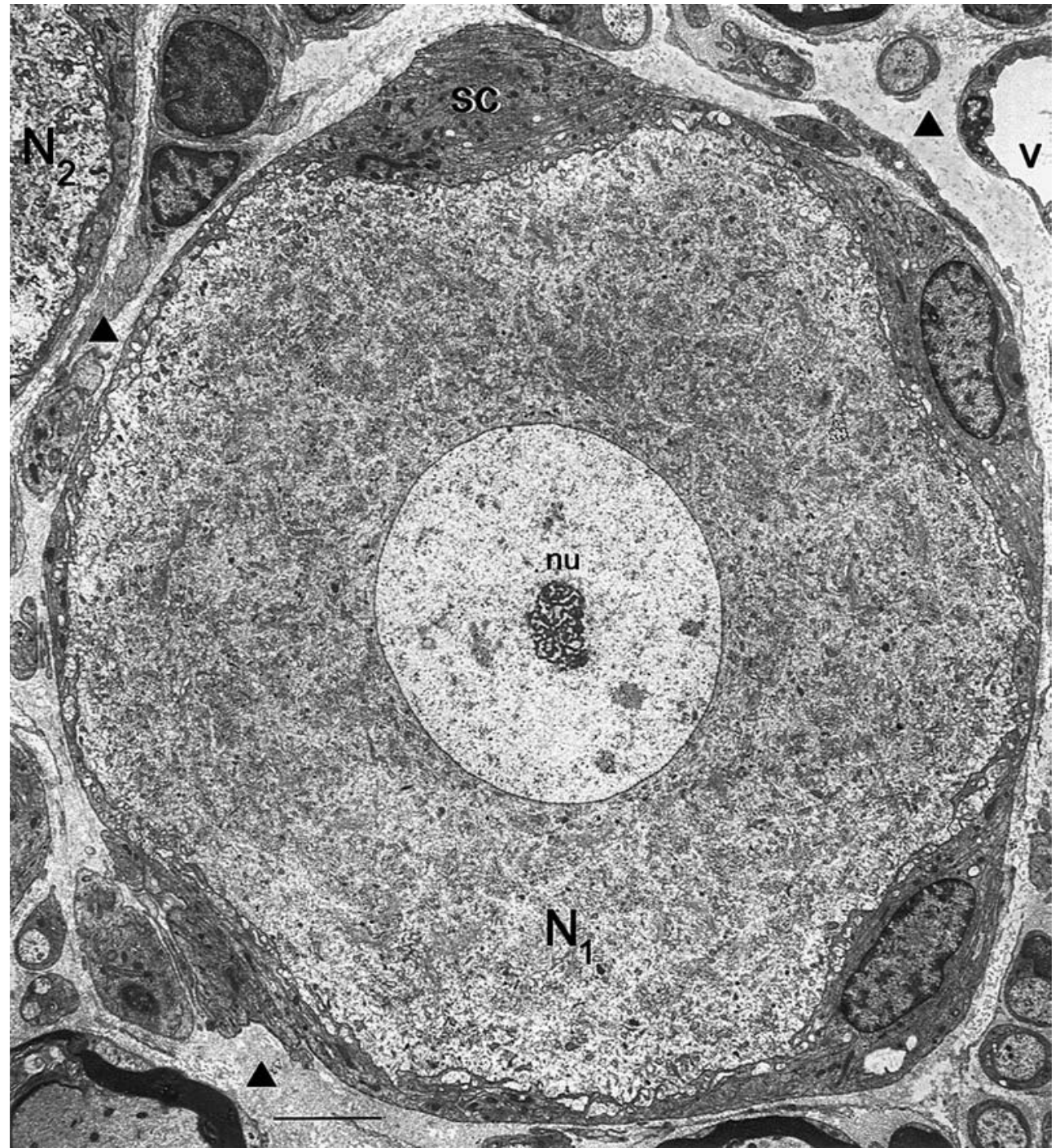


did not differ significantly in young and adult rabbits, but was significantly smaller in old and very old animals (Fig. 3c). The ratio was particularly low in the very old animals, being $\sim 76 \%$ lower than in young animals.

The relations between the volume of the satellite cell sheath and the volume of the related nerve cell body in each unit are shown in Fig. 4 for young, adult and old animals, and in Fig. 5a for very old animals. The regression lines are

Young animals: $\mathrm{Vs}=0.1819 \mathrm{Vn}+371.19$

Adult animals: $\mathrm{Vs}=0.1705 \mathrm{Vn}+26.12$

Old animals: $\mathrm{Vs}=0.1149 \mathrm{Vn}+733.63$

Very old animals: $\mathrm{Vs}=0.0419 \mathrm{Vn}+508.23$

The data presented in these figures show that in all age groups the volume of the perineuronal satellite cell sheath is linearly related to the volume of the nerve cell body.

The linear regression lines for the four age groups are presented together in Fig. 5b. It can be seen that, for a given nerve cell body volume, the volume of the satellite cell sheath is in all cases much smaller in the very old animals than in young, adult and old animals.

\section{Discussion}

We found that the mean volume of the nerve cell bodies increased progressively with advancing age. Studies on neurons innervating the periphery have revealed that the volume of the nerve cell body correlates with the size of its peripheral field of innervation (Levi 1906, 1908; Hahn 1912; Terni 1914; Donaldson and Nagasaka 1918; Netto 1951). In turn, the size of the peripheral field innervated by a given type of neuron usually correlates with the body size of the animal. The body size of the animals we studied increased with age, providing an explanation for the progressive increase in the mean volume of the body of the neurons.

We also found that the mean volume of the satellite cell sheaths was significantly smaller in the very old animals. This reduction in volume could be a physiological or a
Fig. 2 Electron micrograph showing a unit consisting of a nerve cell body $\left(\mathrm{N}_{1}\right)$ and its enveloping satellite cell sheath $(s c)$. The section passes through the nucleolus $(n u)$ of the nerve cell body. A portion of another unit $\left(\mathrm{N}_{2}\right)$ can be seen in the lower left corner of the figure. The satellite cell sheaths of these two units are completely separated by intervening connective tissue (filled triangle). $v$ Blood vessel. Spinal ganglion of a rabbit aged 8.8 years. Scale bar $5 \mu \mathrm{m}$

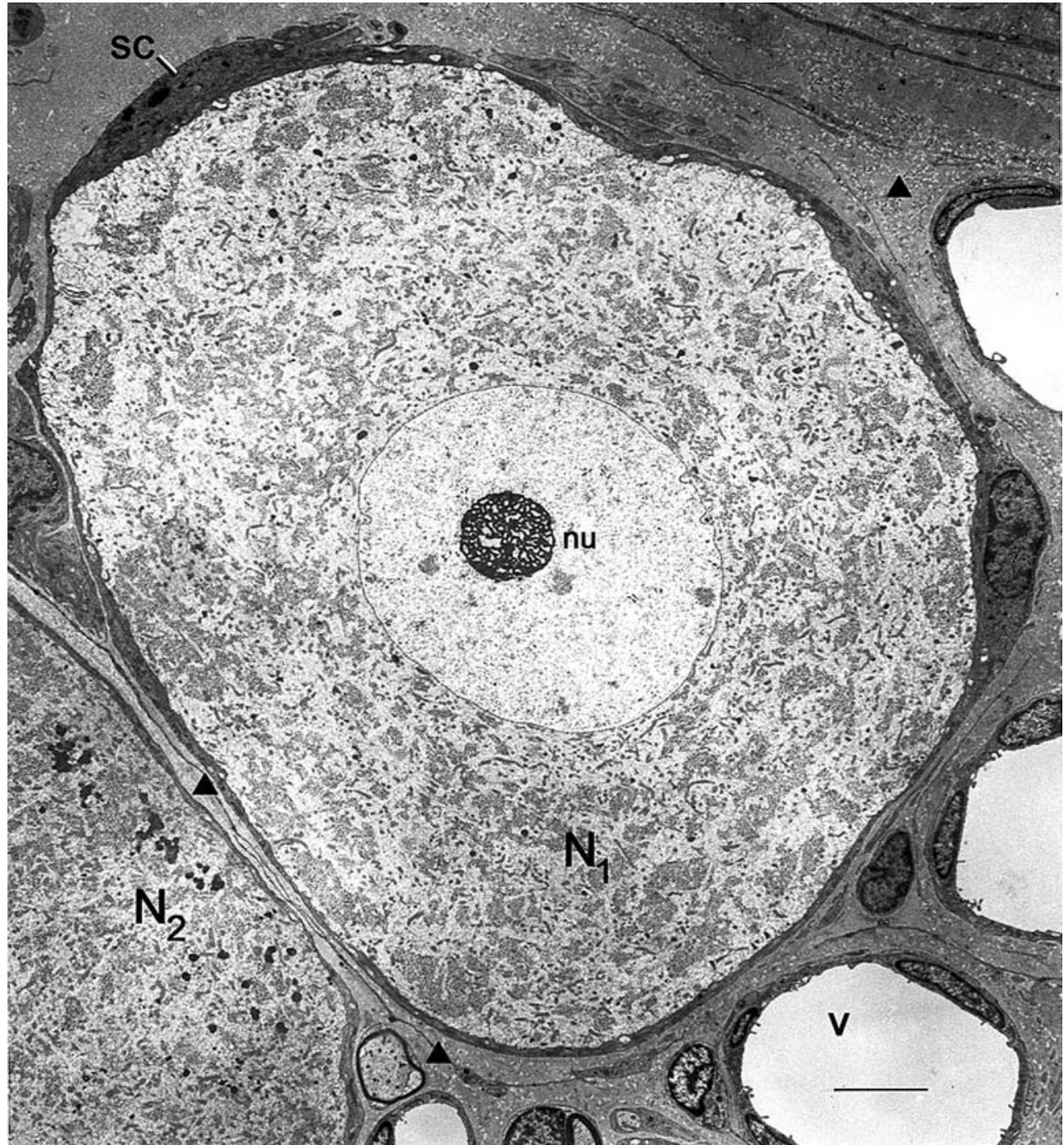


Table 1 Volumes of the satellite cell sheaths and of the nerve cell bodies: mean values for each rabbit

\begin{tabular}{|c|c|c|c|c|c|c|}
\hline Rabbit & $\begin{array}{l}\text { Age } \\
\text { (years) }\end{array}$ & $\begin{array}{l}\text { Number } \\
\text { of ganglia } \\
\text { examined }\end{array}$ & $\begin{array}{l}\text { Total number } \\
\text { of units }{ }^{\mathrm{a}} \\
\text { examined }\end{array}$ & $\begin{array}{l}\text { Mean volume } \\
\text { of the satellite } \\
\text { cell sheaths }\left(\mu \mathrm{m}^{3}\right)\end{array}$ & $\begin{array}{l}\text { Mean volume } \\
\text { of the nerve } \\
\text { cell bodies }\left(\mu \mathrm{m}^{3}\right)\end{array}$ & $\begin{array}{l}\text { Mean volume } \\
\text { ratio between } \\
\text { satellite cell sheaths } \\
\text { and related nerve } \\
\text { cell bodies }\end{array}$ \\
\hline 1 & 1 & 8 & 64 & 4,166 & 15,668 & 0.221 \\
\hline 2 & 1 & 8 & 65 & 3,864 & 15,936 & 0.211 \\
\hline 3 & 1 & 8 & 61 & 3,795 & 15,879 & 0.249 \\
\hline 4 & 3.6 & 8 & 49 & 3,693 & 20,785 & 0.228 \\
\hline 5 & 3.6 & 8 & 54 & 3,868 & 20,658 & 0.220 \\
\hline 6 & 3.6 & 8 & 53 & 3,892 & 19,671 & 0.230 \\
\hline 7 & 6.7 & 8 & 71 & 3,382 & 23,554 & 0.154 \\
\hline 8 & 6.7 & 8 & 58 & 3,594 & 23,740 & 0.171 \\
\hline 9 & 6.7 & 8 & 66 & 3,482 & 23,805 & 0.176 \\
\hline 10 & 8.8 & 8 & 44 & 1,545 & 27,682 & 0.056 \\
\hline 11 & 8.8 & 8 & 55 & 1,674 & 25,395 & 0.053 \\
\hline 12 & 8.8 & 8 & 56 & 1,660 & 25,632 & 0.053 \\
\hline
\end{tabular}

${ }^{\mathrm{a}}$ Each unit consists of a nerve cell body and its own satellite cell sheath

Table 2 Volumes of the satellite cell sheaths and of the nerve cell bodies: mean values for each age group

\begin{tabular}{|c|c|c|c|c|c|c|}
\hline Age group & $\begin{array}{l}\text { Age } \\
\text { (years) }\end{array}$ & $\begin{array}{l}\text { Number of } \\
\text { ganglia examined }\end{array}$ & $\begin{array}{l}\text { Total number } \\
\text { of units } \\
\text { examined }\end{array}$ & $\begin{array}{l}\text { Mean volume } \\
\text { of the satellite } \\
\text { cell sheaths }\left(\mu \mathrm{m}^{3}\right)\end{array}$ & $\begin{array}{l}\text { Mean volume } \\
\text { of the nerve } \\
\text { cell bodies }\left(\mu \mathrm{m}^{3}\right)\end{array}$ & $\begin{array}{l}\text { Mean volume } \\
\text { ratio between } \\
\text { satellite cell sheaths } \\
\text { and related nerve } \\
\text { cell bodies }\end{array}$ \\
\hline Young & 1 & 24 & 190 & $3,940^{\mathrm{a}}$ & $15,829^{\mathrm{e}}$ & $0.227^{\mathrm{i}}$ \\
\hline Adult & 3.6 & 24 & 156 & $3,801^{\mathrm{b}}$ & $20,480^{\mathrm{f}}$ & $0.226^{1}$ \\
\hline Old & 6.7 & 24 & 195 & $3,479^{\mathrm{c}}$ & $23,695^{\mathrm{g}}$ & $0.167^{\mathrm{m}}$ \\
\hline
\end{tabular}

There are no significant differences between ${ }^{\mathrm{a}}$ and ${ }^{\mathrm{b}}$, between ${ }^{\mathrm{b}}$ and ${ }^{\mathrm{c}}$ and between ${ }^{\mathrm{a}}$ and ${ }^{\mathrm{c}}$, whereas the differences between ${ }^{\mathrm{c}}$ and ${ }^{\mathrm{d}}$, between ${ }^{\mathrm{b}}$ and ${ }^{\mathrm{d}}$ and between ${ }^{\mathrm{a}}$ and ${ }^{\mathrm{d}}$ are significant $(P<0.05)$

There are no significant differences between ${ }^{\mathrm{e}}$ and ${ }^{\mathrm{f}}$, between ${ }^{\mathrm{f}}$ and ${ }^{\mathrm{g}}$, between ${ }^{\mathrm{g}}$ and ${ }^{\mathrm{h}}$ and between ${ }^{\mathrm{f}}$ and ${ }^{\mathrm{h}}$, whereas the differences between ${ }^{\mathrm{e}}$ and ${ }^{\mathrm{g}}$ and between ${ }^{\mathrm{e}}$ and ${ }^{\mathrm{h}}$ are significant $(P<0.05)$

There is no significant difference between ${ }^{\mathrm{i}}$ and ${ }^{1}$, whereas the differences between ${ }^{1}$ and ${ }^{\mathrm{m}}$, between ${ }^{\mathrm{m}}$ and ${ }^{\mathrm{n}}$, between ${ }^{\mathrm{i}}$ and ${ }^{\mathrm{m}}$, between ${ }^{1}$ and ${ }^{\mathrm{n}}$ and between ${ }^{1}$ and ${ }^{\mathrm{n}}$ are significant $(P<0.05)$

${ }^{\circ}$ Each unit consists of a nerve cell body and its own satellite cell sheath

Fig. 3 a Mean volumes of nerve cell bodies $(\mathrm{Vn})$, b mean volumes of satellite cell sheaths $(\mathrm{Vs}), \mathrm{c}$ mean values of the volume ratio between the satellite cell sheaths and the related nerve cell bodies (Vs/ $\mathrm{Vn}$ ) in spinal ganglia of rabbits aged 1 year (young, $Y$ ), 3.6 years (adult, $A), 6.7$ years (old, $O$ ) and 8.8 years (very old, $V O)$. Vertical bars indicate the standard errors of the mean
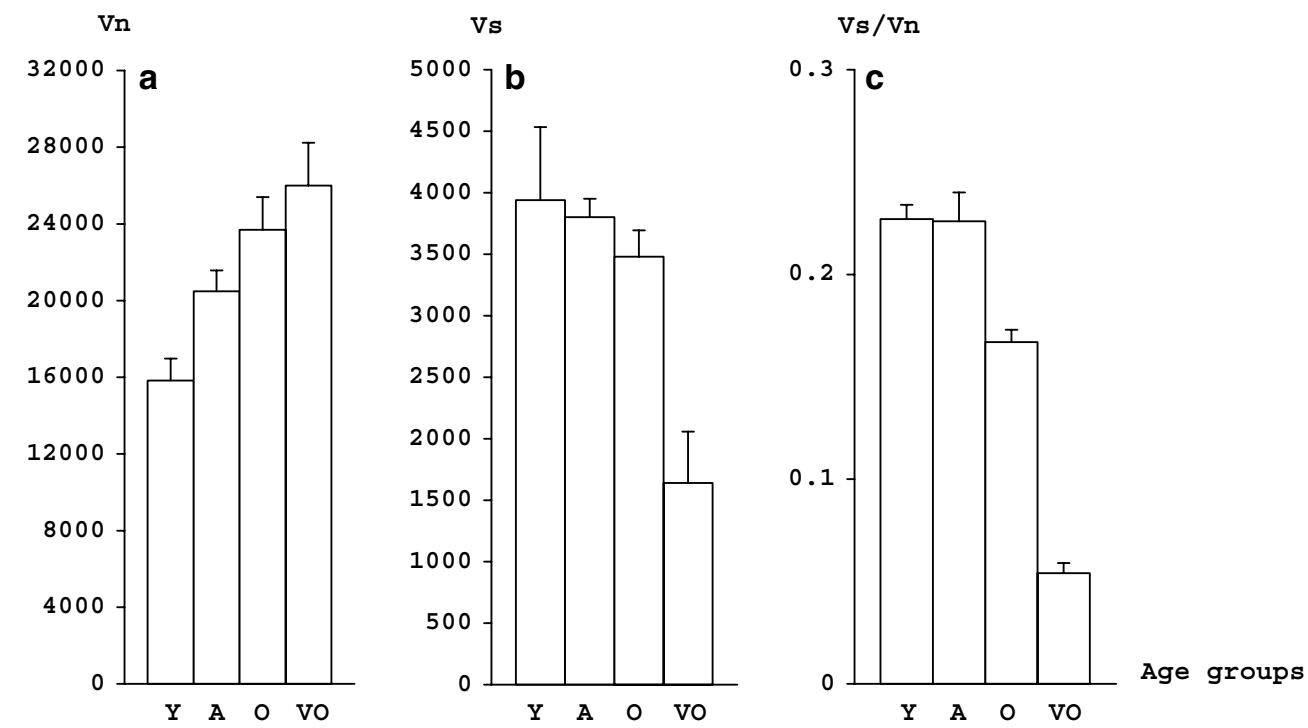
Fig. 4 Relations between the volume of the satellite cell sheath (Vs, ordinate) and the volume of the nerve cell body ( $\mathrm{Vn}$, abscissa) in young, adult and old rabbits. Each $d o t$ represents the value obtained from a single unit. The regression lines for these values are also shown
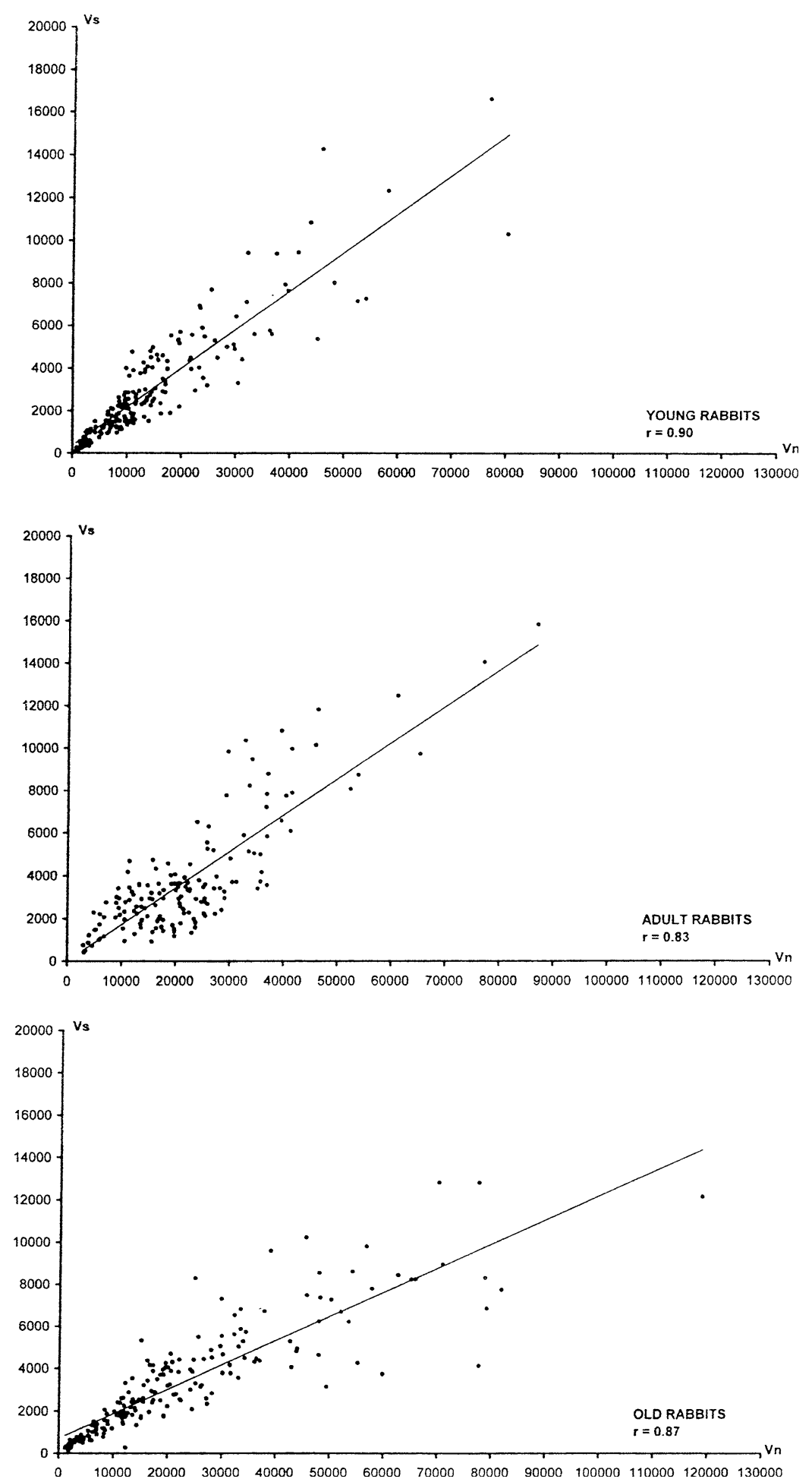

pathological process. To address this issue we note firstly that, in spite of a careful search, none of the structural features that usually accompany pathological processes (nerve cell degeneration, myelin fragmentation, evidence of satellite or Schwann cell proliferation, presence of residual nodules, and presence of leucocytes or macrophages) was found in the ganglia we examined. Furthermore, the reduction in the mean volume of the satellite cell sheaths was of the same amount in all three very old animals. These facts make it extremely unlikely that the decrease in the mean volume of the satellite cell sheath is the result of a pathological process.

The mean value of the volume ratio between the satellite cell sheaths and the related nerve cell bodies was much lower in very old animals. It is difficult to compare the changes in the volume ratio between glial and ner- 
Fig. 5 a Relation between the volume of the satellite cell sheath (Vs, ordinate) and the volume of the nerve cell body (Vn, abscissa) in very old rabbits. Each dot represents the value obtained from a single unit. The regression line for these values is also shown, $\mathbf{b}$ the regression lines of Figs. 4 and a are shown together in order to compare the data for young $(Y)$, adult $(A)$, old $(O)$ and very old $(V O)$ animals
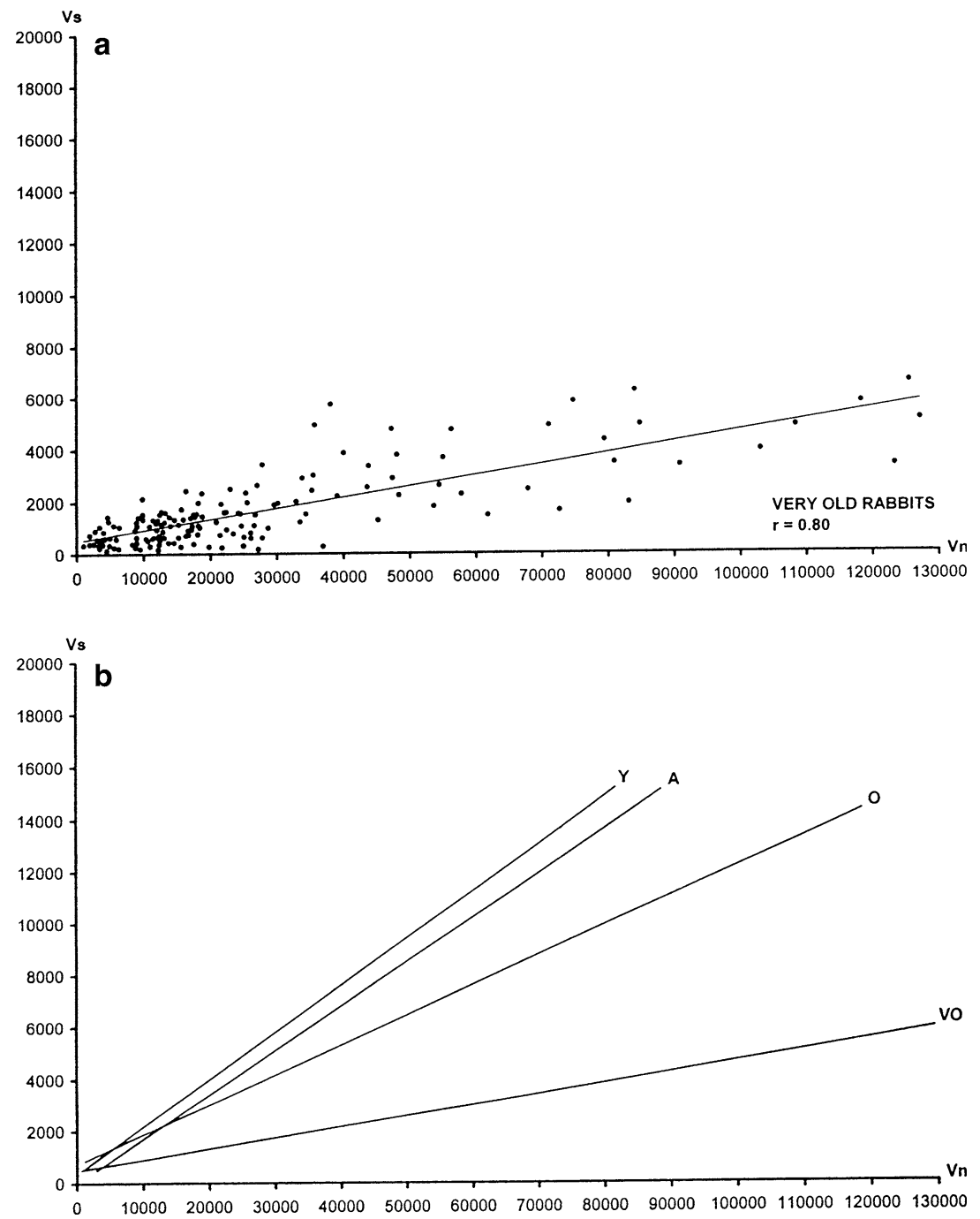

vous tissue we observed with those found in other regions of the nervous system, mainly because the published results are discordant. With regard to the peripheral nervous system, Carney and Lyon (1990) found no age-related changes in the volume fraction of perisomatic satellite cell cytoplasm in the rat vestibular ganglion. In the grey matter of the central nervous system, some authors have reported an increase in the number ratio of glial cells to neurons with age (Brizzee et al. 1968, 1976; Brizzee 1975; Terry et al. 1987; Sturrock 1989c; Peters 1991), others have reported that the volume fraction occupied by glial cells increased with age (Geinisman et al. 1978). By contrast, other authors found that the number of glial cells did not change with age (Vaughan and Peters 1974; Tomlinson and Henderson 1976; Diamond et al. 1977; Diamond and Connor 1981; Sturrock 1988, 1989a, b; Peters et al. 1991). The discrepancies between these results may be due to the different species studied, to the different age studied or to the variety of quantification methods employed. Furthermore, most studies on the grey matter of the central nervous system used light microscope prepara- tions in which it is often difficult to distinguish small neuronal nuclei from glial nuclei. At present, therefore, it is not possible to determine whether the differences between the results obtained in the various regions of the nervous system are due to the above factors or to the various regions of the nervous system being differentially affected by the aging process.

Our analysis also showed that in each age group the volume of the perineuronal satellite cell sheath is linearly related to the volume of the nerve cell body. This result suggests that in rabbit spinal ganglia the quantitative relations between glial and nervous tissue are tightly controlled throughout the life of the animal. This conclusion is in agreement with the results obtained studying adult geckos, lizards and cats (Pannese et al. 1972, 1975). Only hypotheses can be advanced at present regarding the mechanisms by which this tight control is achieved. For example, it is possible that ganglionic neurons release signals influencing and controlling the volume of their associated glial tissue. In the extremely advanced age, the reduced increase (compared to younger ages) in the volume of the satellite cell sheath with increase in the volume 
of the nerve cell body could be due to a reduced release by neurons of the signals to the satellite cells. Alternatively, glial tissue may have reduced ability to respond to signals in extremely advanced age.

That neuronal metabolism reduces in old age has been documented by various studies (e.g. see MeierRuge et al. 1976; Mann et al. 1978; van den Bosch de Aguilar and Vanneste 1980; Finch and Morgan 1990). There is evidence suggesting that satellite cells of sensory ganglia perform the following roles (for more details see Pannese 1981, 1994; Martinelli et al. 2005; Thippeswamy et al. 2005): (1) metabolic support of ganglionic neurons; (2) spatial buffering of ions in the perineuronal microenvironment of the ganglion; (3) control over the traffic of materials to and from the ganglionic neurons; (4) neuroprotection. It is likely that the marked reduction in the volume of the perineuronal satellite cell sheath in very old animals is accompanied by a reduction in these functions with negative consequences for neuronal metabolism.

Finally, it can be noted that the results of this study may constitute a useful reference point for estimating the quantitative changes in the glial tissue, the nervous tissue and their ratios which may occur under experimental and pathological conditions.

\section{References}

Brizzee KR (1975) Gross morphometric analyses and quantitative histology of the aging brain. In: Ordy JM, Brizzee KR (eds) Neurobiology of aging. Plenum Press, New York London, pp 401-423

Brizzee KR, Sherwood N, Timiras PS (1968) A comparison of cell populations at various depth levels in cerebral cortex of young adult and aged long-evans rats. J Gerontol 23:289-297

Brizzee KR, Ordy JM, Hansche J, Kaack B (1976) Quantitative assessment of changes in neuron and glia cell packing density and lipofuscin accumulation with age in the cerebral cortex of a nonhuman primate (Macaca mulatta). In: Terry RD, Gershon S (eds) Neurobiology of aging. Aging, vol 3. Raven Press, New York, pp 229-244

Carney ME, Lyon MJ (1990) Schwann cells associated with vestibular ganglion cells in the aging rat. Am J Otolaryngol 11:228-235

Diamond MC, Connor JR Jr (1981) A search for the potential of the aging brain. In: Enna SJ, Samorajski T, Beer B (eds) Brain neurotransmitters and receptors in aging and age-related disorders. Aging, vol 17. Raven Press, New York, pp 43-58

Diamond MC, Johnson RE, Gold MW (1977) Changes in neuron number and size and glia number in the young, adult, and aging rat medial occipital cortex. Behav Biol 20:409-418

Donaldson HH, Nagasaka G (1918) On the increase in the diameters of nerve-cell bodies and of the fibers arising from them during the later phases of growth (albino rat). J Comp Neurol 29:529-552

Finch CE, Morgan DG (1990) RNA and protein metabolism in the aging brain. Annu Rev Neurosci 13:75-87

Geinisman Y, Bondareff W, Dodge JT (1978) Hypertrophy of astroglial processes in the dentate gyrus of the senescent rat. Am J Anat 153:537-544

Gundersen HJG (1988) The nucleator. J Microsc 151:3-21

Hahn A (1912) Einige Beobachtungen an Riesenlarven von Rana esculenta. Arch mikrosk Anat (I) 80:1-38

Harkness JE, Wagner JE (1983) The biology and medicine of rabbits and rodents, 2nd edn. Lea and Febiger, Philadelphia
Hennig A (1967) Formbestimmung von Körpern aus ebenen Schnitten. In: Elias H (ed) Stereology. Proceedings second international congress for stereology, Chicago. Springer, Berlin Heidelberg New York, pp 83-94

Humbertson A Jr, Zimmermann E, Leedy M (1969) A chronological study of mitotic activity in satellite cell hyperplasia associated with chromatolytic neurons. Z Zellforsch 100:507515

Ledda M, De Palo S, Pannese E (2004) Ratios between number of neuroglial cells and number and volume of nerve cells in the spinal ganglia of two species of reptiles and three species of mammals. Tissue Cell 36:55-62

Levi G (1906) Studi sulla grandezza delle cellule. 1. Ricerche comparative sulla grandezza delle cellule dei Mammiferi. Arch ital Anat Embriol 5:291-358

Levi G (1908) I gangli cerebrospinali. Studi di Istologia comparata e di Istogenesi. Arch ital Anat Embriol 7(Suppl):1-392

Mann DMA, Yates PO, Stamp JE (1978) The relationship between lipofuscin pigment and ageing in the human nervous system. J Neurol Sci 37:83-93

Martinelli C, Sartori P, De Palo S, Ledda M, Pannese E (2005) Increase in number of the gap junctions between satellite neuroglial cells during lifetime: an ultrastructural study in rabbit spinal ganglia from youth to extremely advanced age. Brain Res Bull 67:19-23

Mattfeldt T, Mall G, Gharehbaghi H, Möller P (1990) Estimation of surface area and length with the orientator. J Microsc 159:301-317

Meier-Ruge W, Reichlmeier K, Iwangoff P (1976) Enzymatic and enzyme histochemical changes of the aging animal brain and consequences for experimental pharmacology on aging. In: Terry RD, Gershon S (eds) Neurobiology of aging. Aging, vol 3. Raven Press, New York, pp 379-387

Netto ASpF (1951) Dimensioni e numero dei neuroni in relazione alla mole somatica. Confronti tra due roditori di mole somatica molto differente. Z Zellforsch 36:222-234

Pannese E (1960) Observations on the morphology, submicroscopic structure and biological properties of satellite cells (s.c.) in sensory ganglia of mammals. Z Zellforsch 52:567-597

Pannese E (1964) Number and structure of perisomatic satellite cells of spinal ganglia under normal conditions or during axon regeneration and neuronal hypertrophy. Z Zellforsch 63:568592

Pannese E (1981) The satellite cells of the sensory ganglia. Adv Anat Embryol Cell Biol 65:1-111

Pannese E (1994) Neurocytology. Fine structure of neurons, nerve processes, and neuroglial cells. Georg Thieme Verlag, Stuttgart New York

Pannese E, Bianchi R, Calligaris B, Ventura R, Weibel ER (1972) Quantitative relationships between nerve and satellite cells in spinal ganglia. An electron microscopical study. I. Mammals. Brain Res 46:215-234

Pannese E, Ventura R, Bianchi R (1975) Quantitative relationships between nerve and satellite cells in spinal ganglia: an electron microscopical study. II. Reptiles. J Comp Neurol 160:463-476

Pannese E, Procacci P, Ledda M, Conte V (1996) Age-related reduction of the satellite cell sheath around spinal ganglion neurons in the rabbit. J Neurocytol 25:137-146

Pannese E, Ledda M, Martinelli C, Sartori P (1997a) Age-related decrease of the perineuronal satellite cell number in the rabbit spinal ganglia. J Periph Nerv Syst 2:77-82

Pannese E, Barni L, Arcidiacono G, Ledda M (1997b) Cell body volume of spinal ganglion neurons: estimation by three different methods. J Submicrosc Cytol Pathol 29:497-502

Peters A (1991) Aging in monkey cerebral cortex. In: Peters A, Jones EG (eds) Cerebral cortex, vol 9. Plenum Press, New York London, pp 485-510

Peters A, Josephson K, Vincent SL (1991) Effects of aging on the neuroglial cells and pericytes within area 17 of the rhesus monkey cerebral cortex. Anat Rec 229:384-398 
Sturrock RR (1988) A quantitative histological study of neuroglial number in the retrofacial, facial and trigeminal motor nuclei in the ageing mouse brain. J Anat 161:153-157

Sturrock RR (1989a) Stability of neuron and glial number in the parabigeminal nucleus of the ageing mouse. Acta Anat $134: 322-326$

Sturrock RR (1989b) Stability of neuron and glial number in the abducens nerve nucleus of the ageing mouse brain. $J$ Anat 166:97-101

Sturrock RR (1989c) A quantitative histological study of the anterodorsal thalamic nucleus and the lateral mammillary nucleus of ageing mice. J Hirnforsch 30:191-195

Terni T (1914) Sulla correlazione fra ampiezza del territorio di innervazione e volume delle cellule gangliari. 1. Ricerche sui gangli spinali della coda nei Chelonii. Anat Anz 47:369-386

Terry RD, Deteresa R, Hansen LA (1987) Neocortical cell counts in normal human adult aging. Ann Neurol 21:530-539
Thippeswamy T, McKay JS, Morris R, Quinn J, Wong L-F, Murphy D (2005) Glial-mediated neuroprotection: evidence for the protective role of the NO-cGMP pathway via neuron-glial communication in the peripheral nervous system. Glia 49:197210

Tomlinson BE, Henderson G (1976) Some quantitative cerebral findings in normal and demented old people. In: Terry RD, Gershon S (eds) Neurobiology of aging. Aging, vol 3. Raven Press, New York, pp 183-204

van den Bosch de Aguilar Ph, Vanneste J (1980) Ageing of the spinal ganglion neurons in the rat: a radioautographic study following injection of $\left[{ }^{3} \mathrm{H}\right]$ lysine. Neurosci Lett 18:225-230

Vaughan DW, Peters A (1974) Neuroglial cells in the cerebral cortex of rats from young adulthood to old age: an electron microscope study. J Neurocytol 3:405-429

Weisbroth SH, Flatt RE, Kraus AL (1974) The biology of the laboratory rabbit. Academic, New York San Francisco London 